\section{Synchronized Seed Germination and Seedling Growth of Black Cumin}

\author{
Mohammed Elsayed El-Mahrouk ${ }^{1}$, Mossad Khairy Maamoun ${ }^{2}$, \\ Yaser Hassan Dewir ${ }^{3}$, Antar Nasr El-Banna ${ }^{4}$, Hail Z. Rihan ${ }^{5}$, \\ Ahmed Salamh ${ }^{3}$, Ahmed A. Al-Aizari ${ }^{3}$, and Michael P. Fuller ${ }^{5}$
}

ADDITIONAL INDEX wORDs. herbs, medicinal plants, Ranunculaceae, seed dormancy, seed vigor

SumMARY. Black cumin (Nigella sativa) is an important medicinal plant in the pharmacological industry. It is cultivated on a commercial scale, but its seeds have a slow, unsynchronized germination rate. Enhancing seed germination is crucial for improving the production of black cumin. The influence of presowing treatments [gibberellic acid $\left(\mathrm{GA}_{3}\right)$, potassium nitrate, salicylic acid, and stratification at $4^{\circ} \mathrm{C}$ ] on seed germination was assessed. Seed germination was determined daily for $\mathbf{3 0}$ days, and germination parameters, including final germination percentage (FGP), corrected germination rate, number of days to reach $50 \%$ of FGP, and seedling length vigor index, were evaluated. Endogenous contents of $\mathrm{GA}_{3}$ and abscisic acid (ABA) in nonstratified and stratified seeds were estimated using high-performance liquid chromatography (HPLC) and seedling growth was determined in 45-day-old seedlings. All presowing treatments tended to boost early germination for the first 10 days compared with the control. Low concentrations of $\mathrm{GA}_{3}$ at $0.25 \mathrm{~g} \cdot \mathrm{L}^{-1}$ also increased FGP $(80 \%)$ compared with the control group $(65.55 \%)$. Stratification for 4 weeks provided the greatest FGP value at $95.56 \%$, and stratification for 3 weeks proved to be the most effective treatment for optimal seedling growth. Sodium dodecyl sulphate-polyacrylamide gel electrophoresis patterns of stratified seeds revealed the alteration in intensities of 13 bands and the appearance of a new band $(180 \mathrm{kDa})$ indicating a change in the synthesis of proteins during stratification. Moreover, stratification modulated the endogenous $\mathrm{GA}_{3}$ and $\mathrm{ABA}$ contents of black cumin seeds, which alleviated the physiological dormancy and resulted in high and synchronized seed germination.

$\mathrm{B}$ lack cumin (Nigella sativa) is an annual plant grown in arid and semiarid lands and is native

Received for publication 1 Nov. 2021. Accepted for publication 5 Jan. 2022.

Published online 11 February 2022.

${ }^{1}$ Department of Horticulture, Faculty of Agriculture, Kafrelsheikh University, Kafr El-Sheikh 33516, Egypt

${ }^{2}$ Breeding Department for Vegetable Crops, Aromatic and Medicinal Plants Horticultural Research Institute, Agriculture Research Centre, Giza 12619, Egypt

${ }^{3}$ Plant Production Department, College of Food and Agriculture Sciences, King Saud University, Riyadh 11451, Saudi Arabia

${ }^{4}$ Genetics Department, Faculty of Agriculture, Kafrelsheikh University, Kafr El-Sheikh 33516, Egypt

${ }^{5}$ School of Biological and Marine Sciences, Faculty of Science and Engineering, University of Plymouth, Drake Circus PL4 8AA, UK

We acknowledge Researchers Supporting Project number (RSP-2021/375), King Saud University, Riyadh, Saudi Arabia.

Y.H.D. is the corresponding author. E-mail: ydewir@ksu.edu.sa.

This is an open access article distributed under the CC BY-NC-ND license (https://creativecommons. org/licenses/by-nc-nd/4.0/).

https://doi.org/10.21273/HORTTECH04984-21 to the eastern Mediterranean (Ozer et al., 2020). Black cumin is considered one of the most important medicinal herbs around the world (Yimer et al., 2019). Forouzanfar et al. (2014) reported that black cumin is popular for its use in traditional medicine for treating diseases and disorders such as eczema, back pain, and asthma. This is in addition to its wide use as a spice in food products. The essential oil of black cumin is also widely used in the pharmaceutical and cosmetics industry due to its medicinal properties (Khan et al., 2011). A significant number of studies have confirmed the antioxidant, antihypertensive, antimicrobial, antibacterial, antifungal, antiviral, antiinflammatory, anticancer, and antidiabetic activities, neuroprotective, and analgesic impacts of black cumin (Abdallah, 2017; Abulfadl et al., 2018; Ozdemir et al., 2018; Yimer et al., 2019). The germination of black cumin seeds and the growth of seedlings present a big challenge for achieving high levels of growth and productivity of this crop (Papastylianou et al., 2018). Seeds of black cumin possess dormancy characteristics due to their underdeveloped embryos. In a laboratory investigation conducted during nongrowing season, Rouhi et al. (2012) postulated that black cumin seeds have morpho-physiological dormancy in addition to a physiological component. As a winter annual, black cumin seeds are usually sown in October and November and typically take $10 \mathrm{~d}$ or more to germinate under natural conditions. Low germination percentages and rates are common, resulting in variation of emergence under field conditions.

Stratification and temperature shocks are used to break dormancy in many species (Hidayati et al., 2012; Su et al., 2016). Numerous molecular and physiological changes occur during cold treatment among them, the transcriptional activation and repression of genes by low temperature (Thomashow, 1999). The reprogramming of gene expression results in the accumulation of protective proteins and metabolites which are known to have protective effects. It is also reported that cold treatment could improve the physiological metabolism

\begin{tabular}{llll}
\hline $\begin{array}{l}\text { Units } \\
\text { To convert U.S. to SI, } \\
\text { multiply by }\end{array}$ & U.S. unit & SI unit & $\begin{array}{l}\text { To convert SI to U.S., } \\
\text { multiply by }\end{array}$ \\
\hline 100 & $\mathrm{bar}$ & $\mathrm{kPa}$ & 0.01 \\
29,574 & $\mathrm{fl} \mathrm{oz}$ & $\mu \mathrm{L}$ & $3.3814 \times 10^{-5}$ \\
29.5735 & $\mathrm{fl} \mathrm{oz}$ & $\mathrm{mL}$ & 0.0338 \\
3.7854 & $\mathrm{gal}$ & $\mathrm{L}$ & 0.2642 \\
2.54 & inch(es) & $\mathrm{cm}$ & 0.3937 \\
25.4 & $\operatorname{inch}(\mathrm{es})$ & $\mathrm{mm}$ & 0.0394 \\
1 & $\operatorname{micron}(\mathrm{s})$ & $\mu \mathrm{m}$ & 1 \\
28.3495 & $\mathrm{Oz}$ & $\mathrm{g}$ & 0.0353 \\
0.001 & $\mathrm{ppm}$ & $\mathrm{g} \cdot \mathrm{L}^{-1}$ & 1000 \\
0.1 & $\mathrm{ppm}$ & $\mathrm{mg} / 100 \mathrm{~g}$ & 10 \\
$\left({ }^{\circ} \mathrm{F}-32\right) \div 1.8$ & ${ }^{\circ} \mathrm{F}$ & ${ }^{\circ} \mathrm{C}$ & $\left({ }^{\circ} \mathrm{C} \times 1.8\right)+32$ \\
& & &
\end{tabular}


of the plant, such as increased activities of dehydrogenase, superoxide dismutase (Yin et al., 2005), peroxidase (Jiang et al., 2014), photosynthetic pigments, photosynthetic efficiency, and nitrate reductase activity (Wu et al., 2007). Changes in the synthesis of constitutive proteins and the synthesis of new proteins under low-temperature have confirmed the relationship between protein expression and low temperature (Evstigneeva et al., 2001). Various presowing treatments including chemical and mechanical scarification (Shaik et al., 2008), soaking in plant growth regulators (Chauhan et al., 2009; Dewir et al., 2011; Elhindi et al., 2016; El-Nashar and Dewir, 2019) or other germination promoting substances such as nitrogen-containing compounds (Bethke et al., 2007) are used to overcome seed dormancy and improve seed germination. This investigation explored options to accelerate black cumin seed germination using presowing seed treatments to enhance the uniformity of emergence in field conditions.

\section{Materials and methods}

SEed Materials and PRESOWING TREATMENTS. Seeds of an inbredselected black cumin line [self-pollinated for 3 years (El-Mahrouk et al., 2015)] were used in this investigation and subjected to different presowing treatments (chemical and stratification). The experiment took place during Oct. 2018 at the farm of Kafrelsheikh University (Kafr El-Sheikh, Egypt). For the chemical treatments, dry seeds were soaked in one of 14 aqueous solutions of salicylic acid [SA (Winlab, Market Harborough, UK) ] at $0.05,0.1,0.2$, and $0.4 \mathrm{~g} \cdot \mathrm{L}^{-1}$, potassium nitrate $\left[\mathrm{KNO}_{3}\right.$ (PanReac AppliChem, Darmstadt, Germany)] at $0.5,1,1.5,2.5$, and $3 \mathrm{~g} \cdot \mathrm{L}^{-1}$, or gibberellic acid $\left[\mathrm{GA}_{3}\right.$ (Merck, Darmstadt, Germany)] at $0.25,0.5,1.0,1.5$, and $2 \mathrm{~g} \cdot \mathrm{L}^{-1}$. The soaked seeds were shaken in an orbital shaker for $24 \mathrm{~h}$ under dark conditions, then washed with distilled water and air-dried. In addition to chemical treatments, we explored the use of cold stratification. Dry seeds were wrapped in aluminum foil sheets and transferred to a refrigerator $\left(4^{\circ} \mathrm{C}\right)$ for different time intervals $(0,1,2,3,4$, and 5 weeks). Seeds without treatments served as the negative control, and seeds soaked in distilled water alone for $24 \mathrm{~h}$ served as the positive control treatment.

GERMINATION MEDIUM AND EXPERIMENTAL DESIGN. A mixture of peatmoss and vermiculite $[1: 1 \mathrm{v} / \mathrm{v}$ (Egyptian Company for Mineral Resources, Cairo, Egypt)] was used as the germination medium. The medium was fertilized with $1 \mathrm{~g} \cdot \mathrm{L}^{-1}$ solution containing $19 \mathrm{~N}-8.3 \mathrm{P}-15.7 \mathrm{~K}$ water-soluble fertilizer (Rosasol; Rosier, Moustier, Belgium) and sterilized in $1 \mathrm{~g} \cdot \mathrm{L}^{-1}$ commercial fungicide solution [ $20 \%$ tolclofos-methyl, $30 \%$ thiram (Rizolex; Kafr El-Zayat Company, El-Gharbia, Egypt)]. The $\mathrm{pH}$ of the medium was adjusted to $6 \pm 1$ with calcium carbonate powder using a $\mathrm{pH}$ meter to measure $\mathrm{pH}$ (3510; Jenway, Stafford, UK). The germination mixture was covered with a plastic cover for $24 \mathrm{~h}$ before filling the tray and sowing the seeds. Seeds were sown, one seed in each cell, in expanded polyurethane foam trays $(3.0 \times 3.0-\mathrm{cm}$ cells; 209 cells per tray). Only 100 seeds were sown in each tray to facilitate data recording. The trays were kept in a greenhouse at a temperature of $25 \pm 2{ }^{\circ} \mathrm{C}$ and light intensity of $300 \mu \mathrm{mol} \cdot \mathrm{m}^{-2} \cdot \mathrm{s}^{-1}$ after sowing. The trays were manually watered every week and the same water amount $(\mathrm{l} \mathrm{L})$ was applied to each tray. All treatments were covered with plastic sheets until the first germinated seeds were visible and then the plastic covers were removed.

Data collection. Germination was assessed for $30 \mathrm{~d}$ and daily germination percentages were summed up to obtain the cumulative germination percentage for each treatment on each assessment date. A seed was considered germinated when the cotyledons were visible above the surface and the following five germination parameters were calculated: 1) final germination percentage $($ FGP $)=$ number of germinated seeds (30 d from sowing/ number of sown seeds) $\times 100 ; 2$ ) germination rate index $(\mathrm{GRI})=$ $\left[(\mathrm{Gl} / \mathrm{l})+(\mathrm{G} 2 / 2)+\left(\mathrm{G}_{\mathrm{x}} / \mathrm{X}\right)\right]$ where, $\mathrm{G}=$ germination percentage on each alternate day after placement $1,2, x=$ corresponding day of germination (Esechie, 1994); 3) corrected germination rate index $(\mathrm{CGRI})=(\mathrm{GRI} / \mathrm{FGP}) \times 100 ; 4)$ $\mathrm{GT}_{50}=$ number of days lapsed to reach $50 \%$ of FGP (Hsu et al.1985); $5)$ seedling length vigor index $($ SLVI $)=$ (mean shoot length + mean root length) $\times$ FGP (Ashkan and Jalal, 2013).

After $45 \mathrm{~d}$ of sowing, 20 seedlings were randomly chosen to evaluate seedling growth and the following parameters were recorded for each seedling: lengths (centimeters) of shoot and root (seedlings were washed and the longest root was measured), number of leaves, and fresh and dry weights of shoots and roots (grams). Dry weight was measured after drying for $48 \mathrm{~h}$ at $60^{\circ} \mathrm{C}$.

HPLC ESTIMATION OF PHYTOHORMONES. HPLC extraction procedure was performed according to Shindy and Smith (1975) and abscisic acid (ABA) and $\mathrm{GA}_{3}$ analyses were performed with the modifications described by Dewir et al. (2015). Samples of both stratified (3 weeks), and nonstratified seeds were used for these analyses. Five grams of fresh weight seeds was ground and soaked for $72 \mathrm{~h}$ in aqueous methanol $(80 \%$ $\mathrm{v} / \mathrm{v}$, Merck). The extracts were filtered through Whatman filter paper (No. 42; Sigma-Aldrich Chemie, Taufkirchen, Germany). The filter paper and the residue were reextracted twice with a fresh volume of methanol and filtered. The combined extracts were evaporated to the aqueous phase using a rotary evaporator and the aqueous phase was adjusted to $\mathrm{pH} 2.8$ with $1 \%$ hydrochloric acid (Merck) and extracted three times with ethyl acetate (Merck). It was evaporated to dryness, dissolved in $1 \mathrm{~mL}$ of HPLC methanol, and used for of ABA and $\mathrm{GA}_{3}$ quantification at $254 \mathrm{~nm}$. The extract was filtered through a membrane filter $(0.45 \mu \mathrm{m})$ before injecting $(10 \mu \mathrm{L})$ into a HPLC system (746 data module, 510 pump; Waters, Millford, MA) equipped with a $300 \times$ 3.9-mm column ( $\mu$ Bondapak $\mathrm{Cl} 8$ column, Waters). A mobile phase consisting of methanol HPLC containing $2 \%$ of glacial acetic acid was used at a flow rate of $1.0 \mathrm{~mL} \cdot \mathrm{min}^{-1}$. ABA, and $\mathrm{GA}_{3}$ concentrations in the sample were calculated using the response ratio of the target compound and the appropriate internal standards $\left(\mathrm{GA}_{3}=\right.$ 48880; $\mathrm{ABA}=\mathrm{Al} 049$ ). 
ProteIn EXTRACTION AND SODIUM DODECYL SULPHATE-POLYACRYLAMIDE GEL ELECTROPHORESIS (SDS-PAGE). SDS-PAGE electrophoresis was employed to elucidate the effect of stratification (3 weeks) on protein synthesis. Total proteins were extracted from nonstratified and stratified seeds. Briefly, each sample $(0.5 \mathrm{~g})$ was individually ground into powder with liquid nitrogen. Then, $0.5 \mathrm{~mL}$ of the protein extraction buffer $(62.5 \mathrm{~mm}$ tris hydrochloride, $\mathrm{pH} 6.8,2 \%$ SDS, 10\% glycerol, $5 \% \beta$-mercaptoethanol, $5 \mathrm{M}$ urea and $0.01 \%$ bromophenol blue) was mixed by vortexing. Protein extracts were centrifuged at 14,000 $g_{n}$ for 10 min at $4{ }^{\circ} \mathrm{C}$ and separated by $12 \%$ SDSPAGE according to Laemmli (1970). Molecular weights of different bands were calibrated with a mixture of standard protein markers [11-245 $\mathrm{kDa}$ molecular weight marker (BLUEstain; GoldBio, St. Louis, MO)]. The banding profile was stained by Coomasie blue dye then photographed and scored.

ExPERIMENTAL DESIGN AND STATISTICAL ANALYSIS. The experiment was arranged in a completely randomized design. There were 21 treatments replicated three times and each replicate (one tray) consisted of 100 seeds. The seedling growth parameters were recorded from 10 randomly selected seedlings from each tray. Data of $\mathrm{ABA}, \mathrm{GA}_{3}$, and protein analysis in nonstratified and stratified seeds were analyzed separately. The mean and one-way analysis of variance were calculated using statistical software (SAS ver. 9.13; SAS Institute, Cary, NC). The mean separations were performed using Duncan's multiple range test and least significant difference test.

\section{Results and discussion}

The treatments of water soak for $24 \mathrm{~h}$ (Fig. 1A), $0.25 \mathrm{~g} \cdot \mathrm{L}^{-1} \mathrm{GA}_{3}$ (Fig. 1B), and stratification for 3 to 5 weeks (Fig. IE) improved the timecourse changes in the germination percentage of black cumin compared with the control. The treatments using $\mathrm{KNO}_{3}$ and $\mathrm{SA}$ had reduced effects on seed germination (Fig. 1C-D). All presowing treatments tended to boost earlier germination compared with the control. The treatments with $\mathrm{GA}_{3}$,
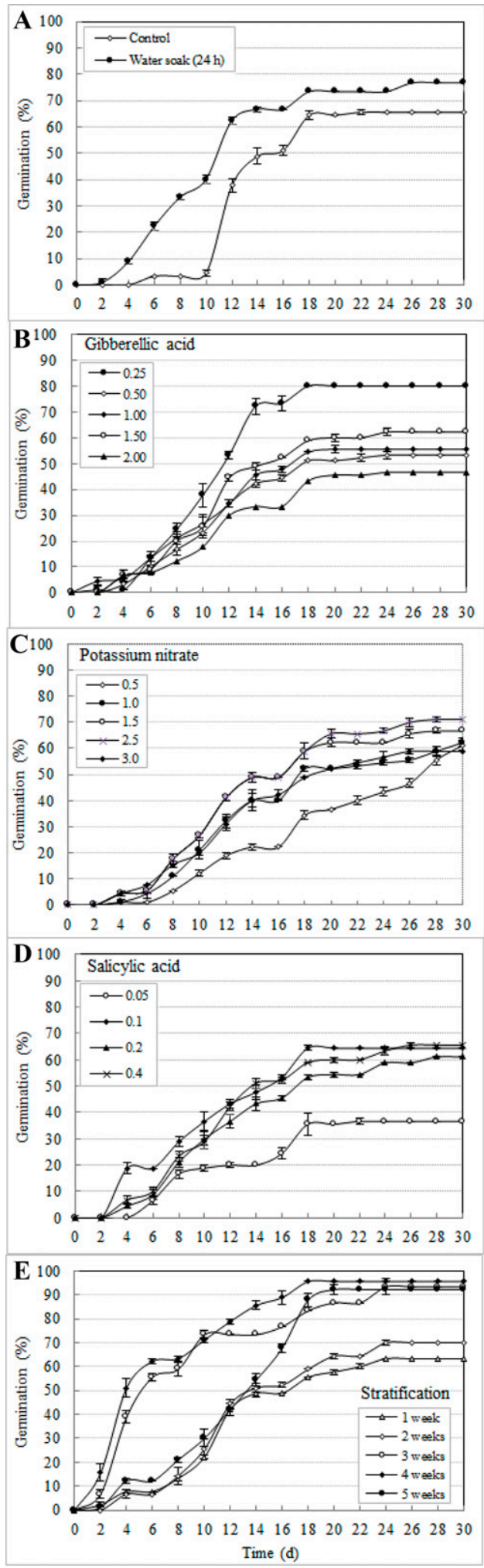

Fig. 1. Time-course changes in germination percentage for black cumin seeds with different presowing treatments: water soak $(24 \mathrm{~h})$, salicylic acid $\left(0.05-0.4 \mathrm{~g} \cdot \mathrm{L}^{-1}\right)$, potassium nitrate $\left(0.5-3.0 \mathrm{~g} \cdot \mathrm{L}^{-1}\right)$, gibberellic acid $\left(0.25-2.0 \mathrm{~g} \cdot \mathrm{L}^{-1}\right)$, and stratification at $2^{\circ} \mathrm{C}$ [35.6 ${ }^{\circ} \mathrm{F}$ (1-5 weeks)] during Oct. 2018 at the farm of Kafrelsheikh University (Kafr El-Sheikh, Egypt). Data presented are mean \pm SE. Nontreated seeds are the control; $1 \mathrm{~g} \cdot \mathrm{L}^{-1}=1000 \mathrm{ppm}$. 
$\mathrm{KNO}_{3}$, and SA concentrations, as well as stratification duration, also caused variations in seed germination over the full culture period. Water soak for $24 \mathrm{~h}$ increased the FGP from $65.55 \%$ (control) to $76.66 \%$ (Table 1 ). $\mathrm{GA}_{3}$ at 0.25 g. $\mathrm{L}^{-1}$ also promoted FGP to $80 \%$. The highest FGP $(93.44,95.56$, and 92.22) were recorded for stratification treatments (Fig. 1E) at 3, 4, and 5 weeks, respectively. The relationships between FGP and the concentrations of pre sowing treatments revealed negative impact of SA $\left[r^{2}=0.010\right.$ (Fig. 2A)] and $\mathrm{KNO}_{3}\left[r^{2}=0.004\right.$ (Fig. 2B)] while high correlations with $\mathrm{GA}_{3}\left[r^{2}=0.56\right.$ (Fig. 2C) $]$ and stratification $\left[r^{2}=0.79\right.$ (Fig. 2D) $]$ were observed. The highest CGRI and the lowest $\mathrm{GT}_{50}$ were observed at 4 weeks of stratification while the highest seedling vigor occurred with 2 to 4 weeks of stratification (Table 1). Germination speed (CGRI and $\mathrm{GT}_{50}$ ) of the seeds because of stratification treatments was significant for black cumin. The seeds reached $50 \%$ of their final germination in a minimum time $(7.2 \mathrm{~d}) \mathrm{com}$ pared with control $(13.53 \mathrm{~d})$. High $\mathrm{GA}_{3}$ concentrations $\left(\geq 0.5 \mathrm{~g} \cdot \mathrm{L}^{-1}\right)$ as well as all SA concentrations showed inhibitory effects on seed germination.

The impermeability of resistant seeds to both water and oxygen is a major constraint on germination in many species. Speedy germination with high germination rates can frequently be achieved by soaking seeds in water for 12 to $48 \mathrm{~h}$. However, the response is species dependent. For example, high seed germination (98.6\%) of tomato (Solanum lycopersicum) could be obtained using water soaking for $12 \mathrm{~h}$ (Sabongari and Aliero, 2004). However, in this study, the water-soaking $(24 \mathrm{~h})$ treatment improved seed germination of black cumin by only $10 \%$. This is consistent with the investigation by Shaik et al. (2008) in which germination capacity of cancer bush (Sutherlandia frutescens) was similar to that of the control after soaking $(24 \mathrm{~h})$ in water. For black cumin, high $\mathrm{GA}_{3}$ concentration (1.25 g. $\left.\mathrm{L}^{-1}\right)$ recorded maximum FGP (76\%) (Rouhi et al., 2012). However, our results indicated that low concentrations of $\mathrm{GA}_{3} \quad(0.25$ $\left.\mathrm{g} \cdot \mathrm{L}^{-1}\right)$, rather than higher concentrations $\left(>0.25 \mathrm{~g} \cdot \mathrm{L}^{-1}\right)$, had stimulatory effects $\left(80 \%\right.$ FGP). Moreover, $\mathrm{GA}_{3}$ $\left(0.25 \mathrm{~g} \cdot \mathrm{L}^{-1}\right)$ stimulated germination by $14.45 \%$ as compared with nontreated seeds. These different responses indicate the variable dormancy state of black cumin seeds through storage until the sowing. Gibberellin accumulation is often associated with dormancy release and seed germination (Finkelstein et al., 2008) by overcoming the effects of growth inhibitors (Rehman and Park, 2000). $\mathrm{GA}_{3}$

Table 1. Effect of presowing seed treatments on final germination percentage (FGP), corrected germination rate index (CGRI), time taken to reach $50 \%$ of final germination percentage $\left(\mathrm{GT}_{50}\right)$, and seed length vigor index (SLVI) in black cumin after $30 \mathrm{~d}$ in culture during Oct. 2018 at the farm of Kafrelsheikh University (Kafr El-Sheikh, Egypt).

\begin{tabular}{|c|c|c|c|c|}
\hline \multirow[b]{2}{*}{ Treatment } & \multicolumn{4}{|c|}{ Seed germination parameters ${ }^{\mathrm{z}}$} \\
\hline & FGP (\%) & CGRI & $\mathrm{GT}_{50}(\mathrm{~d})$ & SLVI \\
\hline Control & $65.55 \mathrm{def}^{y}$ & $46.98 \mathrm{~g}$ & $13.53 \mathrm{bc}$ & $18.156 \mathrm{ab}$ \\
\hline \multicolumn{5}{|c|}{ Salicylic acid $\left(\mathrm{g} \cdot \mathrm{L}^{-1}\right)^{\mathrm{x}}$} \\
\hline 0.05 & $36.66 \mathrm{k}$ & $55.77 \mathrm{ef}$ & 12.38 cde & $11.24 \mathrm{~h}$ \\
\hline 0.1 & $64.45 \mathrm{efg}$ & $69.56 c$ & $10.31 \mathrm{~g}$ & $13.82 \mathrm{fg}$ \\
\hline \multicolumn{5}{|c|}{ Potassium nitrate $\left(\mathrm{g} \cdot \mathrm{L}^{-1}\right)$} \\
\hline 0.5 & 57.78 hi & $29.52 \mathrm{~h}$ & $20.00 \mathrm{a}$ & 16.58 bcde \\
\hline 1.0 & $62.23 \mathrm{fgh}$ & $46.68 \mathrm{~g}$ & $14.69 \mathrm{~b}$ & $17.63 \mathrm{abcd}$ \\
\hline 1.5 & $66.67 \mathrm{def}$ & $53.89 \mathrm{efg}$ & $12.82 \mathrm{~cd}$ & $14.17 \mathrm{fg}$ \\
\hline 2.5 & $71.12 \mathrm{~cd}$ & $51.86 \mathrm{fg}$ & $13.34 \mathrm{bc}$ & $13.38 \mathrm{fgh}$ \\
\hline 1.0 & $55.56 \mathrm{i}$ & $66.29 \mathrm{~cd}$ & $10.88 \mathrm{fg}$ & $14.39 \mathrm{efg}$ \\
\hline 1.5 & $62.23 \mathrm{fgh}$ & 59.37 def & $11.60 \mathrm{defg}$ & $15.63 \mathrm{cdef}$ \\
\hline 2.0 & $46.67 \mathrm{j}$ & 57.93 ef & $12.15 \mathrm{cdef}$ & $13.06 \mathrm{gh}$ \\
\hline \multicolumn{5}{|l|}{ Stratification (weeks) } \\
\hline 1 & $63.34 \mathrm{fgh}$ & $57.50 \mathrm{ef}$ & $12.41 \mathrm{cde}$ & $15.24 \mathrm{efg}$ \\
\hline 2 & $70.00 \mathrm{de}$ & $53.60 \mathrm{efg}$ & $12.90 \mathrm{~cd}$ & $17.87 \mathrm{abc}$ \\
\hline 3 & $93.44 \mathrm{a}$ & $85.67 \mathrm{~b}$ & $8.72 \mathrm{~h}$ & $19.27 \mathrm{a}$ \\
\hline 4 & $95.56 \mathrm{a}$ & $97.04 \mathrm{a}$ & $7.20 \mathrm{i}$ & $17.63 \mathrm{abcd}$ \\
\hline 5 & $92.22 \mathrm{a}$ & $54.67 \mathrm{efg}$ & $12.86 \mathrm{~cd}$ & $15.43 \mathrm{def}$ \\
\hline \multicolumn{5}{|l|}{ Significance } \\
\hline LSD value & $5.74 *$ & $7.99 *$ & $1.47^{*}$ & $2.24^{*}$ \\
\hline
\end{tabular}



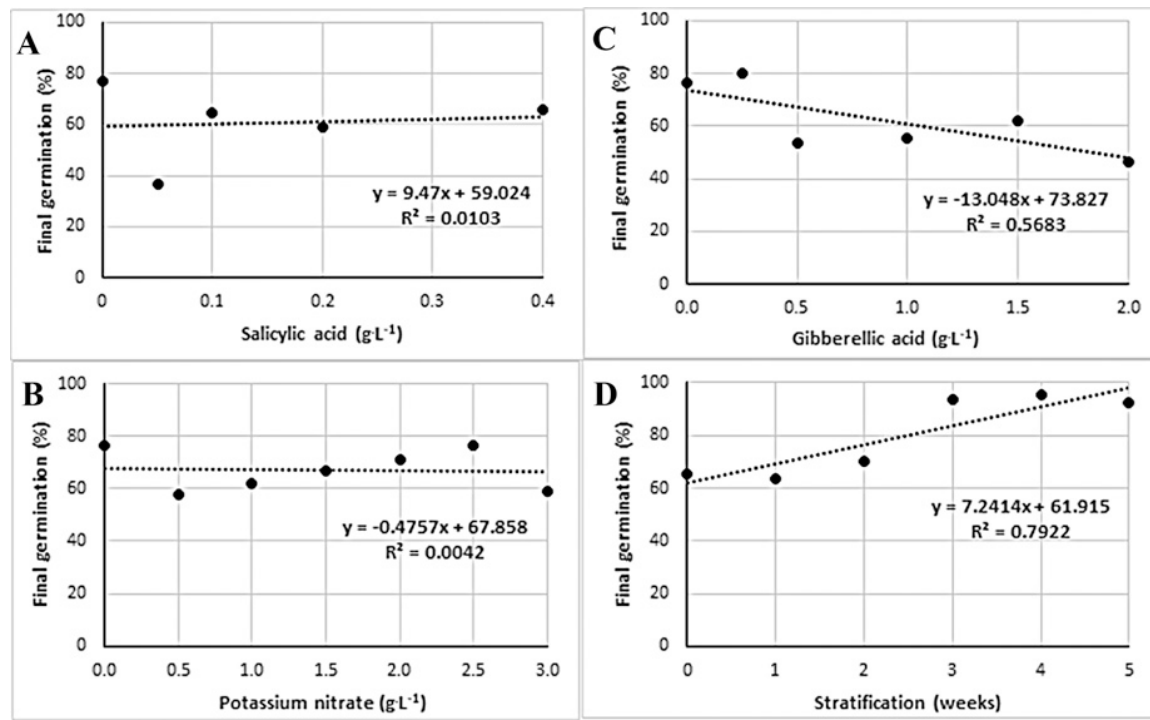

Fig. 2. Relationship between final germination percentages of black cumin seeds and concentrations of (A) salicylic acid, (B) potassium nitrate, (C) gibberellic acid, and (D) stratification at $2{ }^{\circ} \mathrm{C}\left[35.6{ }^{\circ} \mathrm{F}(1-5\right.$ weeks $\left.)\right]$ presowing treatments during $\mathrm{Oct}$. 2018 at the farm of Kafrelsheikh University (Kafr El-Sheikh, Egypt); $1 \mathrm{~g} \cdot \mathrm{L}^{-1}=1000 \mathrm{ppm}$.

promotes the activity of enzymes such as endo- $\beta$-mannanase, which loosen cell walls within the endosperm, thereby reducing resistance to radicle emergence (Yamaguchi and Kamiya, 2002). Moreover, $\mathrm{GA}_{3}$ activates $\alpha$ amylase, which digests the available carbohydrate into simpler sugars, so that energy and nutrition are easily available for faster growth of seedlings (Wani et al., 2014). Dormant seeds that require chilling, dry storage after ripening, and light as a germination stimulator, are often combined with $\mathrm{GA}_{3}$ to overcome their dormancy with varied responses to its concentrations. Al-Hawezy (2013) reported that $\mathrm{GA}_{3}$ concentration $\left(>0.25 \mathrm{~g} \cdot \mathrm{L}^{-1}\right)$ quickly diminished the germination rate of loquat (Eriobotrya japonica).

Priming of black cumin seeds with $3 \% \mathrm{KNO}_{3}$ improved seed germination by $20 \%$ compared with nonprimed seeds under osmotic stress $(-3$ bar) conditions (Balouchi et al., 2015). Nitrogen-containing compounds have been shown to improve seed germination and seed vigor by breaking seed dormancy (Bethke et al., 2007). However, their effects are concentration and plant species dependent. For example, Dewir et al. (2011) reported that $90 \%$ seed germination of cabbage palmetto (Sabal palmetto) was obtained at $1 \% \mathrm{KNO}_{3}$ but higher concentrations reduced seed germination. Conversely, for key thatch palm (Thrinax morrisii), high $\mathrm{KNO}_{3}$ concentrations (4\%) increased seed germination $(80 \%)$, whereas low concentrations had negative effects. These compounds also proved to be effective germination stimulants under stress conditions. It has been documented that $\mathrm{KNO}_{3}$ raises the ambient oxygen levels by making less oxygen available for the citric acid cycle (Bewley and Black, 1983). Previous investigations on seed germination of black cumin during the nongrowing season by Rouhi et al. (2012) reported that $\mathrm{KNO}_{3}(0.3 \%)$ stimulated germination by $76.6 \%$, during off-season, whereas nontreated seeds did not germinate. In the present investigation, $\mathrm{KNO}_{3}$ $\left(2.5 \mathrm{~g} \cdot \mathrm{L}^{-1}\right)$ slightly stimulated seed germination by $5.57 \%$, and nontreated seeds achieved $65.55 \%$ germination. Clearly, $\mathrm{KNO}_{3}$ treatment could be used to break the dormancy of black cumin seeds after harvesting and during storage (Rouhi et al., 2012), but in the present study, it was not shown to be effective to obtain synchronized germination during the sowing and cultivation seasons. In the present investigation, the presowing treatment of black cumin seeds with SA did not improve germination. However, previous studies pointed out that SA facilitates seed germination under saline and drought stresses (Anaya et al., 2018; Carvalho et al., 2007; Farhadi et al., 2016).

Cold stratification has been reported to stimulate de novo GA biosynthesis leading to seed germination (Oh et al., 2006). In this study, ABA and $\mathrm{GA}_{3}$ contents in stratified black cumin increased compared with nonstratified seeds (Fig. 3A and B). Previous studies addressed the positive effects of stratification on seed germination of several plant species, including devil's dung [Ferula assafoetida (Raisi et al., 2013)] and wild celery [Kelussia odoratissima (Shaykhi et al., 2015)]. In arabidopsis (Arabidopsis thaliana), exposure of imbibed seeds to cold conditions resulted in increased expression of GA20oxl and GA20ox2 (Yamauchi et al., 2004). Moreover, it has been demonstrated that a cold stratification period can synchronize germination (Baskin and Baskin, 2014). For black cumin, Rouhi et al. (2012) reported that cold stratification for 3 weeks at $5 \pm$ $1{ }^{\circ} \mathrm{C}$ resulted in $82 \%$ seed germination, whereas in our investigation, $95.56 \%$ seed germination was recorded for 4 weeks cold stratification at $4{ }^{\circ} \mathrm{C}$. We also noted that prolonged cold stratification for 5 weeks resulted in a decline in germination (92.22\%). SDS-PAGE banding patterns revealed 20 scorable bands with different molecular weights (Table 2, Fig. 4). Among them, 14 bands showed high variability. However, the other six bands were commonly detected in the stratified and nonstratified seeds. The most visible alterations in SDS-PAGE patterns of stratified seeds were the alteration in band intensities $(100,75,72,68,63$, $62,50,48,40,39,35,34$, and $33 \mathrm{kDa}$ ) and the appearance of a new band $(180 \mathrm{kDa})$. Many of the 

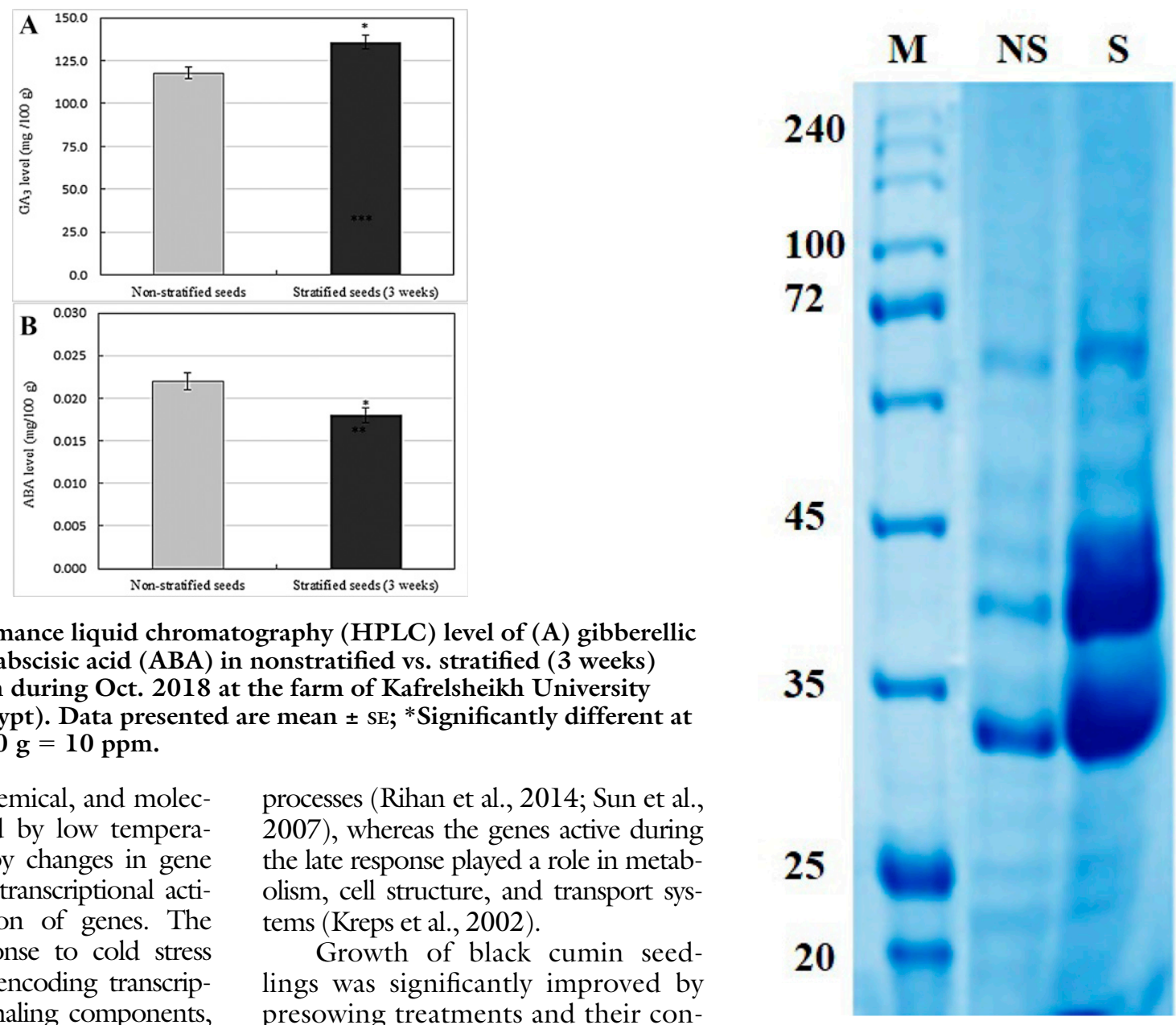

Fig. 3. High-performance liquid chromatography (HPLC) level of (A) gibberellic acid $\left(\mathrm{GA}_{3}\right)$ and $(\mathrm{B})$ abscisic acid (ABA) in nonstratified vs. stratified (3 weeks) seeds of black cumin during Oct. 2018 at the farm of Kafrelsheikh University (Kafr El-Sheikh, Egypt). Data presented are mean $\pm \mathrm{SE}$; ${ }^{*}$ Significantly different at $P \leq 0.05 ; 1 \mathrm{mg} / 100 \mathrm{~g}=10 \mathrm{ppm}$.

physiological, biochemical, and molecular changes caused by low temperature are triggered by changes in gene expression, and the transcriptional activation and repression of genes. The early transient response to cold stress encompasses genes encoding transcription factors, cell signaling components, and those involved in detoxification

processes (Rihan et al., 2014; Sun et al., 2007), whereas the genes active during the late response played a role in metabolism, cell structure, and transport systems (Kreps et al., 2002).

Growth of black cumin seedlings was significantly improved by presowing treatments and their concentrations (Table 3 ). Although low

Table 2. Sodium dodecyl sulphate-polyacrylamide gel electrophoresis banding patterns of total protein isolated from 3 weeks stratified and nonstratified (control) black cumin seeds during Oct. 2018 at the farm of Kafrelsheikh University (Kafr El-Sheikh, Egypt).

\begin{tabular}{lccc}
\hline Band no. & Molecular mass (kDa) & Nonstratified seeds & Stratified seeds \\
\hline 1 & 180 & - & + \\
2 & 100 & + & ++ \\
3 & 75 & + & ++ \\
4 & 72 & + & ++ \\
5 & 68 & ++ & +++ \\
6 & 63 & + & ++ \\
7 & 62 & + & ++ \\
8 & 50 & + & ++ \\
9 & 48 & ++ & +++ \\
10 & 40 & +++ & ++++ \\
11 & 39 & +++ & ++++ \\
12 & 35 & + & ++++ \\
13 & 34 & ++ & ++++ \\
14 & 33 & ++++ & ++++ \\
15 & 32 & + & + \\
16 & 30 & + & + \\
17 & 25 & + & + \\
18 & 24 & + & + \\
19 & 23 & + & + \\
20 & 20 & + & + \\
\hline$=$
\end{tabular}

Fig. 4. Sodium dodecyl sulphatepolyacrylamide gel electrophoresis showing protein bands patterns of 3 weeks stratified $(S)$ and nonstratified [NS (control)] black cumin seeds during Oct. 2018 at the farm of Kafrelsheikh University (Kafr ElSheikh, Egypt); $M=11-245 \mathrm{kDa}$ molecular weight marker (BLUEstain; GoldBio, St. Louis, MO).

concentration of $\mathrm{GA}_{3}$ at $0.25 \mathrm{~g} \cdot \mathrm{L}^{-1}$ enhanced seed germination, it did not favor seedling growth. Stratification treatment for 3 weeks resulted in statistically greater fresh and dry weights than the control. However, no significant differences were recorded for shoot and root length, or number of leaves compared with control. Number of leaves was not significantly influenced by stratification treatments. The highest seedling length and dry weight were attained from stratification of wild celery seeds for 12 weeks (Shaykhi et al., 2015). Dhupper (2013) reported that cold water pre-treatment $(24 \mathrm{~h})$ resulted in the best 
Table 3. Effect of presowing seed treatments on seedling growth of black cumin after $45 \mathrm{~d}$ in culture during Oct. 2018 at the farm of Kafrelsheikh University (Kafr El-Sheikh, Egypt).

\begin{tabular}{|c|c|c|c|c|c|}
\hline \multirow[b]{2}{*}{ Treatment } & \multicolumn{5}{|c|}{ Seedling growth parameters ${ }^{\mathrm{z}}$} \\
\hline & $\begin{array}{c}\text { Shoot } \\
\text { length }(\mathrm{cm})\end{array}$ & $\begin{array}{c}\text { Root length } \\
(\mathrm{cm})\end{array}$ & $\begin{array}{c}\text { Leaves } \\
\text { (no./seedling) }\end{array}$ & $\begin{array}{c}\text { Fresh wt } \\
\text { (g/seedling) }\end{array}$ & $\begin{array}{c}\text { Dry wt } \\
(\mathrm{g} / \text { seedling })\end{array}$ \\
\hline Control & $8.00 \mathrm{ab}^{\mathrm{y}}$ & $9.5 \mathrm{abc}$ & $4.7 \mathrm{abc}$ & $0.2715 \mathrm{~d}$ & $0.047 \mathrm{de}$ \\
\hline Water soak (24 h) & $7.67 \mathrm{ab}$ & $9.34 \mathrm{abc}$ & $5.00 \mathrm{a}$ & $0.323 \mathrm{c}$ & $0.057 \mathrm{~b}$ \\
\hline \multicolumn{6}{|c|}{ Salicylic acid $\left(\mathrm{g} \cdot \mathrm{L}^{-1}\right)^{\mathrm{z}}$} \\
\hline 0.05 & 5.34 fgh & $5.54 \mathrm{~h}$ & $4.16 \mathrm{bcd}$ & $0.214 \mathrm{fgh}$ & $0.036 \mathrm{hi}$ \\
\hline 0.1 & $6.17 \mathrm{defg}$ & $7.0 \mathrm{efgh}$ & $4.33 \mathrm{bcd}$ & $0.230 \mathrm{fg}$ & $0.037 \mathrm{hi}$ \\
\hline 0.2 & 6.24 cdefg & 7.50 defg & $4.00 \mathrm{~cd}$ & $0.206 f-j$ & $0.035 \mathrm{i}$ \\
\hline 0.4 & 7.00 bcde & $6.44 \mathrm{gh}$ & $4.17 \mathrm{bcd}$ & $0.205 \mathrm{f}-\mathrm{j}$ & $0.040 \mathrm{~g}$ \\
\hline \multicolumn{6}{|c|}{ Potassium nitrate $\left(\mathrm{g} \cdot \mathrm{L}^{-1}\right)$} \\
\hline 0.5 & 7.00 bcde & $9.00 \mathrm{abcd}$ & $4.66 \mathrm{abc}$ & 0.236 ef & $0.039 \mathrm{gh}$ \\
\hline 1.0 & $6.34 \mathrm{cdef}$ & $10.67 \mathrm{a}$ & $5.00 \mathrm{a}$ & $0.264 \mathrm{de}$ & $0.043 \mathrm{f}$ \\
\hline 1.5 & $5.5 \mathrm{fgh}$ & $80.0 \mathrm{cdefg}$ & $4.34 \mathrm{bcd}$ & $0.180 \mathrm{ijk}$ & $0.035 \mathrm{i}$ \\
\hline 2.5 & $6.00 \mathrm{efg}$ & $6.67 \mathrm{fgh}$ & $3.67 \mathrm{de}$ & $0.179 \mathrm{ijk}$ & $0.030 \mathrm{jk}$ \\
\hline 3.0 & $5.167 \mathrm{gh}$ & 8.67 bcde & $4.66 \mathrm{abc}$ & $0.163 \mathrm{k}$ & $0.0261 \mathrm{~m}$ \\
\hline \multicolumn{6}{|c|}{ Gibberellic acid $\left(\mathrm{g} \cdot \mathrm{L}^{-1}\right)$} \\
\hline 0.25 & $5.84 \mathrm{fg}$ & 7.84 cdefg & $4.16 \mathrm{bcd}$ & $0.185 \mathrm{~h}-\mathrm{k}$ & $0.037 \mathrm{hi}$ \\
\hline 0.5 & $5.167 \mathrm{gh}$ & 8.34 bcdef & $4.17 \mathrm{bcd}$ & $0.175 \mathrm{jk}$ & $0.028 \mathrm{kl}$ \\
\hline 1.0 & $5.34 \mathrm{fgh}$ & 8.5 bcde & $3.84 \mathrm{de}$ & $0.208 \mathrm{f}-\mathrm{i}$ & $0.032 \mathrm{j}$ \\
\hline 1.5 & $6.34 \mathrm{cdef}$ & 8.67 bcde & $3.67 \mathrm{de}$ & $0.159 \mathrm{k}$ & $0.027 \mathrm{~lm}$ \\
\hline 2.0 & $4.60 \mathrm{~h}$ & 8.00 cdefg & $3.16 \mathrm{e}$ & $0.190 \mathrm{~g}-\mathrm{k}$ & $0.025 \mathrm{~m}$ \\
\hline \multicolumn{6}{|l|}{ Stratification (weeks) } \\
\hline 1 & $6.27 \mathrm{cdefg}$ & 8.34 bcdef & $4.67 \mathrm{abc}$ & $0.224 \mathrm{f}$ & $0.035 \mathrm{i}$ \\
\hline 2 & $7.17 \mathrm{bcd}$ & $10.00 \mathrm{ab}$ & $5.00 \mathrm{a}$ & $0.362 \mathrm{~b}$ & $0.052 \mathrm{c}$ \\
\hline 3 & $8.50 \mathrm{a}$ & $9.84 \mathrm{ab}$ & $5.00 \mathrm{a}$ & $0.428 \mathrm{a}$ & $0.064 \mathrm{a}$ \\
\hline 4 & $7.34 \mathrm{bc}$ & $9.34 \mathrm{abc}$ & $4.83 \mathrm{ab}$ & $0.305 \mathrm{c}$ & $0.048 \mathrm{~d}$ \\
\hline 5 & $7.84 \mathrm{ab}$ & $6.67 \mathrm{fgh}$ & $5.00 \mathrm{a}$ & $0.220 \mathrm{fg}$ & 0.045 ef \\
\hline \multicolumn{6}{|l|}{ Significance } \\
\hline LSD value & $1.12 *$ & $1.71^{*}$ & $0.719^{*}$ & $0.031 *$ & $0.002 *$ \\
\hline
\end{tabular}

${ }^{\mathrm{z}} \mathrm{l} \mathrm{cm}=0.3937$ inch, $1 \mathrm{~g}=0.0353 \mathrm{oz}, \mathrm{l} \mathrm{g} \cdot \mathrm{L}^{-1}=1000 \mathrm{ppm}$.

'Values followed by the same letter in the same column are not significantly different at $P \leq 0.05$ according to Duncan's multiple range test.

* Significant at $P \leq 0.05$.

growth behavior of arabic gum tree (Acacia nilotica), lebbeck (Albizzia lebbeck), and ghaf (Prosopis cineraria). It has been generally noted that presowing chemical treatments did not enhance seedlings growth compared with water soaking treatment or the control treatment. Application of presowing cold stratification treatment has been reported to improve seedlings growth.

\section{Conclusions}

Our investigation confirmed that black cumin seeds possess physiological dormancy. Stratification treatments (3 and 4 weeks) increased final seed germination and speed of germination leading to synchronization of seed germination during the sowing season. Cold stratification modulated $\mathrm{GA}_{3}$ and $\mathrm{ABA}$ levels and proved effective to release seed dormancy. This could positively improve the total yield of this medicinally important plant.

\section{Literature cited}

Abdallah, E.M. 2017. Black seed (Nigella sativa) as antimicrobial drug: A minireview. Nov. Appro. Drug Des. Dev. 3(1): 555603, https://doi.org/10.19080/NAP DD.2017.03.555603.

Abulfadl, Y.S., N.N. El-Maraghy, A.A.E. Ahmed, S. Nofal, and O.A. Badary. 2018. Protective effects of thymoquinone on Dgalactose and aluminum chloride induced neurotoxicity in rats: Biochemical, histological and behavioral changes. Neurol. Res. 40:324-333, https://doi.org/10.1080/ 01616412.2018.1441776.

Al-Hawezy, S.M.N. 2013. The role of the different concentrations of GA3 on seed germination and seedling growth of loquat (Eriobotrya japonica L.). J. Agr. Vet. Sci. 4(5):03-06, https://doi.org/ 10.21271/zjpas.v27i4.219.

Anaya, F., R. Fghire, S. Wahbi, and K. Loutfi. 2018. Influence of salicylic acid on seed germination of Vicia faba L. under salt stress. J. Saudi Soc. Agr. Sci. 17:1-8, https://doi.org/10.1016/j.jssas. 2015.10.002.

Ashkan, A. and M. Jalal. 2013. Effect of salinity on seed germination and seedling vigor indices of two halophytic plant species (Agropyron elongatum and A. pectiniforme). Int. J. Agr. Crop Sci. 5:2669-2676.

Balouchi, H., S.A. Dehkordi, M.M. Dehnavi, and B. Behzadi. 2015. Effect of priming types on germination of Nigella sativa under osmotic stress. South-West. J. Hort. Biol. Environ. 6:1-20.

Baskin, C.C. and J.M. Baskin. 2014. Seeds: Ecology, biogeography, and evolution of dormancy and germination. 2nd ed. Elsevier/Academic Press, San Diego, CA.

Bethke, P.C., I.G.L. Libourel, and R.L. Jones. 2007. Nitric oxide in seed dormancy and germination, p. 153-175. In: K.J. Bradford and H. Nonogaki (eds.). Seed development, dormancy and germination. Blackwell Publ., Oxford, UK. 
Bewley, J.D. and M. Black. 1983. Physiology and biochemistry of seeds in relation to germination. Springer-Verlag, Berlin, Germany.

Carvalho, P.R., N.B. Machado Neto, and C.C. Custodio. 2007. Salicylic acid in marigold (Calendula officinalis L.) under different stresses. Rev. Bras. Sementes 29:114-124.

Chauhan, J.S., A. Tomar, N.I. Singh, S. Ali, and A. Debarati. 2009. Effect of growth hormones on seed germination and seedling growth of black gram and horse gram. J. Amer. Sci. 5:79-84.

Dewir, Y.H., M.E. El-Mahrouk, and A.F. Omar. 2015. Molecular characterization of 16SrII phytoplasma group and associated down-regulation of ABA and IAA in Opuntia caracasana. Phytopathogenic Mollicutes 5:100-106, https://doi.org/ 10.5958/2249-4677.2015.00068.7.

Dewir, Y.H., M.E. El-Mahrouk, and Y. Naidoo. 2011. Effects of some mechanical and chemical treatments on seed germination of Sabal palmetto and Thrinax morrisii palms. Aust. J. Crop Sci. 5:248-253.

Dhupper, R. 2013. Effect of seed pretreatment on survival percentage of three desert tree species. J. Environ. Sci. (China) 2:776-786.

Elhindi, K.M., Y.H. Dewir, A.W. Asrar, E. Abdel-Salam, A.S. El-Din, and M. Ali. 2016. Improvement of seed germination in three medicinal plant species by plant growth regulators. HortScience 51:887-891, https://doi.org/10.21273/ HORTSCI.51.7.887.

El-Mahrouk, M.E., M.K. Maamoun, Y.H. Dewir, S.A. Omran, and A.N. ELBanna. 2015. Morphological and molecular characterization of induced mutants in Nigella sativa L. using irradiation and chemical mutagens. Egypt. J. Plant Breed. 19:257-272.

El-Nashar, Y.I. and Y.H. Dewir. 2019. Stimulation of germination and seedling vigor in dormant seeds of african juniper. HortTechnology 29:874-879, https://doi. org/10.21273/HORTTECH04452-19.

Esechie, H. 1994. Interaction of salinity and temperature on the germination of sorghum. J. Agron. Crop Sci. 172:194-199, https://doi.org/10.1111/j.1439-037X. 1994.tb00166.x.

Evstigneeva, Z.G., N.A. Solov'eva, and L.I. Sidel'nikova. 2001. Structures and functions of chaperones and chaperones. Appl. Biochem. Microbiol. 37:1-13.

Farhadi, N., A. Estaji, and S. Alizadeh Salteh. 2016. The effect of pretreatment of salicylic acid on seed germination of milk thistle (Silybum marianum cv. Budakalaszi) under salinity and drought stress. Iran. J. Seed Res. 3:75-84.

Finkelstein, R., W. Reeves, T. Ariizumi, and C. Steber. 2008. Molecular aspects of seed dormancy. Annu. Rev. Plant Biol. 59:387-415.

Forouzanfar, F., B.S.F. Bazzaz, and H. Hosseinzadeh. 2014. Black cumin (Nigella sativa) and its constituent (thymoquinone): A review on antimicrobial effects. Iran. J. Basic Med. Sci. 17:929-938.

Khan, A., H.C. Chen, M. Tania, and D.Z. Zhang. 2011. Anticancer activities of Nigella sativa (black cumin). Afr. J. Tradit. Complement. Altern. Med. 8(5S): 226-232, https://doi.org/10.4314/ajtcam. v8i5SS.10.

Hidayati, S.N., J.L. Walck, D.J. Merritt, S.R. Turner, D.W. Turner, and W. Kingsley. 2012. Sympatric species of Hibbertia (Dilleniaceae) vary in dormancy break and germination requirements: Implications for classifying morphophysiological dormancy in Mediterranean biomes. Ann. Bot. 109:1111-1123, https://doi.org/ $10.1093 / \mathrm{aob} / \mathrm{mcs} 034$.

Hsu, F.H., C.J. Nelson, and A.G. Matches. 1985. Temperature effects on germination of perennial warm-season forage grasses. Crop Sci. 25:212-220.

Jiang, J., Y. Lu, J. Li, L. Li, X. He, H. Shao, and Y. Dong. 2014. Effect of seed treatment by cold plasma on the resistance of tomato to Ralstonia solanacearum (bacterial wilt). PLoS One 9:e97753, https://doi.org/10.1371/journal.pone.00 97753.

Kreps, J.A., Y. Wu, H.S. Chang, T. Zhu, X. Wang, and J.F. Harper. 2002. Transcriptome changes for Arabidopsis in response to salt, osmotic, and cold stress. Plant Physiol. 130:2129-2141, https:// doi.org/10.1104/pp.008532.

Laemmli, U.K. 1970. Cleavage of structural proteins during the assembly of the head of bacteriophage T4. Nature 227:680-685.

Oh, E., S. Yamaguchi, Y. Kamiya, G. Bae, W.I. Chung, and G. Choi. 2006. Light activates the degradation of PIL5 protein to promote seed germination through gibberellin in Arabidopsis. Plant J. 47:124-139, https://doi.org/10.1111/ j.1365-313X.2006.02773.x.

Ozdemir, N., M.N. Kantekin-Erdogan, T. Tat, and A. Tekin. 2018. Effect of black cumin oil on the oxidative stability and sensory characteristics of mayonnaise. J. Food Sci. Technol. 55:1562-1568, https://doi. org/10.1007/s13197-018-3075-4.
Ozer, H., F. Coban, U. Sahin, and S. Ors. 2020. Response of black cumin (Nigella sativa L.) to deficit irrigation in a semi-arid region: Growth, yield, quality, and water productivity. Ind. Crops Prod. 144:112048, https://doi.org/10.1016/ j.indcrop.2019.112048.

Papastylianou, P., N.N. Bakogianni, I. Travlos, and I. Roussis 2018. Sensitivity of seed germination to salt stress in black cumin (Nigella sativa L.). Not. Bot. Hortic. Agrobot. CLUG-NAPOCA 46: 202-205, https://doi.org/10.15835/nbha 46110861 .

Raisi, A., S.M. Nabavi Kalat, and A.R. Sohani Darban. 2013. The investigation effects of stratification, temperature and potassium nitrate on seed dormancy breaking Ferula assafoetida. World Appl. Sci. J. 21:379-383, https://doi.org/10.5829/ idosi.wasj.2013.21.3.2785.

Rehman, S. and I. Park. 2000. Effect of scarification, GA and chilling on the germination of golden rain tree (Lrenteria paniculata Laxm.) seeds. Scientia Hort. 85:319-324, https://doi.org/10.1016/ S0304-4238(00)00126-6.

Rihan, H.Z., M. Al-Issawi, M. Al Shamari, W.A. Woldie, M. Kiernan, and M.P. Fuller. 2014. The effect of molybdenum on the molecular control of cold tolerance in cauliflower (Brassica oleracea var. botrytis) artificial seeds. Plant Cell Tissue Organ Cult. 118:215-228, https://doi.org/10.1007/ s11240-014-0475-7.

Rouhi, H.R., A. Sepehri, and F. Karimi. 2012. Study of dormancy-breaking of black cumin seeds (Nigella sativa L.). Ann. Biol. Res. 3:2651-2655.

Sabongari, S. and B.L. Aliero. 2004. Effects of soaking duration on germination and seedling growth of tomato (Lycopersicum esculentum Mill). Afr. J. Biotechnol. 3:47-51, https://doi.org/10.5897/AJB20 04.000-2008.

Shaik, S., Y.H. Dewir, N. Singh, and A. Nicholas. 2008. Influences of pre-sowing seed treatments on germination of the cancer bush (Sutherlandia frutescens), a reputed medicinal plant in arid environments. Seed Sci. Technol. 36:795-801, https://doi. org/10.15258/sst.2008.36.3.31.

Shaykhi, A.H., B.M. Nassiry, and M.A. Kachouei. 2015. Effect of some treatments on seed dormancy, germination and antioxidant enzymes of Kelussia odoratissima Mozaff. Seeds. Cercet. Agron. Mold. 8:79-90, https://doi.org/10.1515/ cerce-2015-0032.

Shindy, W.W. and O.E. Smith. 1975. Identification of plant hormones from cotton ovules. Plant Physiol. 55:550-554, https://doi.org/10.1104/pp.55.3.550. 
Su, L., Q. Lan, H.W. Pritchard, H. Xue, and X. Wang. 2016. Reactive oxygen species induced by cold stratification promote germination of Hedysarum scoparium seeds. Plant Physiol. Biochem. 109:406-415, https://doi.org/10.1016/j.plaphy.2016. 10.025 .

Sun, M.M., L.H. Li, H. Xie, R.C. Ma, and Y.K. He. 2007. Differentially expressed genes under cold acclimation in Physcomitrella patens. J. Biochem. Mol. Biol. 40:986-1001, https://doi.org/10.5483/ BMBRep.2007.40.6.986.

Thomashow, M.F. 1999. Plant cold acclimation: Freezing tolerance genes and regulatory mechanisms. Annu. Rev. Plant Physiol. Plant Mol. Biol. 50:571-599, https://doi.org/10.1146/annurev.arplant. 50.1.571.
Wani, R.A., T.H. Malik, A.R. Malik, J.A. Baba, and N.A. Dar. 2014. Studies on apple seed germination and survival of seedlings as affected by gibberellic acid under cold arid conditions. Int. J. Sci. Technol. Res. 3:2010-2016.

Wu, Z.H., L.H. Chi, S.F. Bian, and K.Z. $\mathrm{Xu}$. 2007. Effects of plasma treatment on maize seeding resistance. J. Maize Sci. 15:111-113, https://doi.org/10.4236/ as.2020.114026.

Yamaguchi, S. and Y. Kamiya. 2002. Gibberellins and light-stimulated germination. J. Plant Growth Regul. 20: 369-376, https://doi.org/10.1007/s0034 40010035 .

Yamauchi, Y., M. Ogawa, A. Kuwahara, A. Hanada, Y. Kamiya, and S. Yamaguchi.
2004. Activation of gibberellin biosynthesis and response pathways by low temperature during imbibitions of Arabidopsis thaliana seeds. Plant Cell 16:367-378, https://doi.org/10.1105/ tpc.018143.

Yimer, E.M., K.B. Tuem, A. Karim, N. Ur-Rehman, and F. Anwar. 2019. Nigella sativa L. (black cumin): A promising natural remedy for wide range of illnesses. Evid. Based Complement. Alternat. Med. 1528635, https://doi.org/10.1155/2019/ 1528635.

Yin, M.Q., M.J. Huang, B.Z. Ma, and T.C. Ma. 2005. Stimulating effects of seed treatment by magnetized plasma on tomato growth and yield. Plasma Sci. Technol. 7:3143-3147, https://doi.org/ 10.1088/1009-0630/7/6/017. 